Article

\title{
Evaluation of the Total Mercury Weight Exposure Distribution Using Tree Bark Analysis in an Artisanal and Small-Scale Gold Mining Area, North Gorontalo Regency, Gorontalo Province, Indonesia
}

\author{
Hendra Prasetia ${ }^{1,2, *}$, Masayuki Sakakibara ${ }^{3,4} \mathbb{D}$, Koichiro Sera ${ }^{5}$ and Jamie Stuart Laird ${ }^{6}(\mathbb{D}$ \\ 1 Graduate School of Science and Engineering, Ehime University, Matsuyama 790-8577, Japan \\ 2 Department of Forestry, Faculty of Agriculture, University of Lampung, Bandar Lampung 35145, Indonesia \\ 3 Research Institute for Humanity and Nature, Kyoto 603-8047, Japan; sakaki@chikyu.ac.jp \\ 4 Faculty of Collaborative Regional Innovation, Ehime University, Matsuyama 790-8577, Japan \\ 5 Cyclotron Research Center, Iwate Medical University, Tomegamori 348-58 Tomegamori, \\ Takizawa 020-0173, Japan; ksera@iwate-med.ac.jp \\ 6 School of Chemistry, University of Melbourne, Parkville, VIC 3010, Australia; jslaird@unimelb.edu.au \\ * Correspondence: hendra.prasetia@fp.unila.ac.id
}

Citation: Prasetia, H.; Sakakibara, M.; Sera, K.; Laird, J.S. Evaluation of the Total Mercury Weight Exposure

Distribution Using Tree Bark Analysis in an Artisanal and Small-Scale Gold Mining Area, North Gorontalo Regency, Gorontalo Province, Indonesia. Int. J. Environ. Res. Public Health 2022, 19, 33. https://doi.org/10.3390/ ijerph19010033

Academic Editor: Richard A. Lord

Received: 17 November 2021

Accepted: 18 December 2021

Published: 21 December 2021

Publisher's Note: MDPI stays neutral with regard to jurisdictional claims in published maps and institutional affiliations.

Copyright: () 2021 by the authors Licensee MDPI, Basel, Switzerland. This article is an open access article distributed under the terms and conditions of the Creative Commons Attribution (CC BY) license (https:// creativecommons.org/licenses/by/ $4.0 /)$.

\begin{abstract}
It is well known that atmospheric mercury $(\mathrm{Hg})$ contaminates air, water, soil, and living organisms, including trees. Therefore, tree bark can be used for the environmental assessment of atmospheric contamination because it absorbs heavy metals. This study aimed to establish a new biomonitoring for the assessment of atmospheric $\mathrm{Hg}$ pollution. Reporting on atmospheric $\mathrm{Hg}$ contamination in an artisanal and small-scale gold mining (ASGM) area in North Gorontalo, Indonesia, we calculated the total weight of $\mathrm{Hg}$ ( $\mathrm{THg}$ ) and quantitatively measured the concentrations of $\mathrm{Hg}$ in the tree bark of Mangifera indica, Syzygium aromaticum, Terminalia catappa, and Lansium domesticum. The $\mathrm{THg}$ of $\mathrm{Hg}$ in the $\mathrm{M}$. indica tree bark samples ranged from not detected (ND) to $74.6 \mu \mathrm{g}$ dry weight (DW) per sample. The total $\mathrm{Hg}$ in the tree bark of S. aromaticum, T. catappa, and L. domesticum ranged from ND to 156.8, ND to 180, and ND to $63.4 \mu \mathrm{g}$ DW, respectively. We concluded that topography significantly influences the accumulation of $\mathrm{Hg}$ together with local weather conditions. A mapped distribution of the THg suggested that the distribution of THg in the tree bark was not affected by the distance to the amalgamation site. Therefore, tree bark can be used as biomonitoring of atmospheric $\mathrm{Hg}$ contamination for the assessment of ASGM areas.
\end{abstract}

Keywords: atmospheric; mercury; ASGM; amalgamation; accumulation; tree bark

\section{Introduction}

Artisanal and small-scale gold mining (ASGM), which provides income to many poor communities in developing countries, such as Indonesia, uses several gold extraction methods that use mercury $(\mathrm{Hg})$. The International Labor Organization estimates that there are currently around 13 million artisanal miners in 55 countries [1]. During the processes of panning and amalgamation when amalgam is burned in a small charcoal fire, ASGM releases $\mathrm{Hg}$ into the atmosphere [2,3]. ASGM is a widely recognized major source of $\mathrm{Hg}$ contamination, and its activities cause serious $\mathrm{Hg}$ pollution.

Mercury is extremely dangerous and contaminates air, water, soil, and living organisms. The health of miners and people living within or outside ASGM areas is affected by the inhalation of atmospheric $\mathrm{Hg}$ [3]. Anthropogenic $\mathrm{Hg}$ emissions to the atmosphere significantly interfere with the natural $\mathrm{Hg}$ cycle [4]; however, estimates of natural global $\mathrm{Hg}$ emissions vary by orders of magnitude [4,5]. The increasing total weight of $\mathrm{Hg}(\mathrm{THg})$ in the soil is likely due to the deposition of $\mathrm{Hg}$ released into the atmosphere [6].

Plants are sensitive to their environmental conditions, and their elemental compositions actively reflect changes in these conditions [7-9]. Tree bark, in particular, can be 
used to assess the status of the environment, especially the level of $\mathrm{Hg}$ contamination, and sources of pollution can be traced by the enrichment of trace elements in tree bark [10]. Airborne particles, trapped within the structure of tree bark, accumulate over several years [11]. The uptake of trace elements by plants involves both root uptake and foliar absorption, including from the deposition of particulate matter on leaves [12]. Different plant uptake patterns are based on three factors: plant species, element species, and conditions at specific sites [13]. Canopy crops act to trap gaseous and particulate $\mathrm{Hg}$, which can then be trapped by tree bark depending on its roughness and porosity [14].

Although the use of tree bark has been studied for environmental pollution assessments, corresponding atmospheric contamination has not been comprehensively discussed in relation to the distance from the source of the contamination and the transport of $\mathrm{Hg}$ in the atmosphere. Consequently, the practical application of tree bark as a biomonitoring for the atmosphere has not been previously proposed. Therefore, several tropical species, including Mangifera indica, Syzygium aromaticum, Terminalia catappa, and Lansium domesticum, were comprehensively studied to establish a new biomonitoring for the assessment of atmospheric $\mathrm{Hg}$ pollution in an ASGM area in North Gorontalo Regency, Gorontalo Province, Indonesia.

\section{Materials and Methods}

\subsection{Sampling Plots}

We performed a field survey and laboratory analyses to determine heavy metal concentrations (particularly $\mathrm{Hg}$ ) in tree bark to assess the environmental contamination in the study area. This study research was conducted during August and September 2016, entering the rainy season in Indonesia, in an ASGM area of north Gorontalo Regency. In this regency, there are three ASGM sites, which are located in different districts, shown in Figure 1. The study area of this research was located in east Sumalata District, shown in Figure 1. This study was obtained tree bark about 65 samples in total with details 21 samples of $M$. indica, 20 samples of $S$. aromaticum, 15 samples of T. catappa, and 9 samples of L. domesticum from the study area, as shown in Figure 2, and sampled randomly selected that were around settlements area. The mercury is very harmful to humans and, therefore, the tree barks samples, mostly found in the inhabitant's yard, were selected in this study due to its capability as biomonitoring of atmospheric Hg contamination. These sampling species were grown naturally in this area, which dominated in the lower topography of this area.

The tree bark samples were collected from $1.3 \mathrm{~m}$ above the ground, being the diameter at breast height standard height. The bark was collected as $10 \times 10 \mathrm{~cm}$ fragments to ensure homogeneous sampling. About $12-18 \mathrm{~cm}^{2}$ of $100 \mathrm{~cm}^{2}$ bark samples were analyzed to indicate the $\mathrm{Hg}$ concentrations.

\subsection{Analytical Methods}

The tree bark samples were dried at $\sim 80{ }^{\circ} \mathrm{C}$ for 2 days in a ventilated oven. About $12-18 \mathrm{~cm}^{2}$ of each sample was crushed to a fine powder with a powder mill (Varian PM2005 m, Osaka Chemical Co., Ltd., Osaka, Japan) to produce homogeneous samples for particle-induced X-ray emission (PIXE) analysis. The tree bark powders (30 mg) were then digested by a mixture of indium (In) and $\mathrm{HNO}_{3}$ in a ratio of 3:100 before the heavy metal concentrations, such as $\mathrm{Pb}, \mathrm{Zn}, \mathrm{Fe}, \mathrm{Hg}$, and As, were determined by PIXE [15-17] at Iwate Medical University (Iwate, Japan). The dimensions of the tree bark samples were calculated by ImageJ, Version 1.48 software. The analytical conditions followed [15]. A small cyclotron provided a $2.9 \mathrm{MeV}$-proton beam on the target after passing through a beam collimator of graphite. The maximum beam intensity on the target was approximately $40 \mathrm{nA}$ for a beam spot diameter of $2 \mathrm{~mm}$ and $80 \mathrm{nA}$ for a diameter of $6 \mathrm{~mm}$. Elements from $\mathrm{Na}$ to $\mathrm{U}$ were detected by two ORTEC Si (Li) detectors. The elements heavier than Ca were detected by the first detector, which had a $0.025 \mathrm{~mm}$-thick Be window and a $6 \mathrm{~mm}$ active diameter, with X-rays with an energy resolution of $154 \mathrm{eV}$ at $5.9 \mathrm{keV}$ and a 300 to $500 \mu \mathrm{m}$ 
thick Mylar absorber inserted between the target and the detector. The other low atomic number elements were detected by the second detector, which had a $0.008 \mathrm{~mm}$ Be window and a $4 \mathrm{~mm}$ active diameter, a resolution of $157 \mathrm{eV}$, and a small graphite aperture without an absorber.
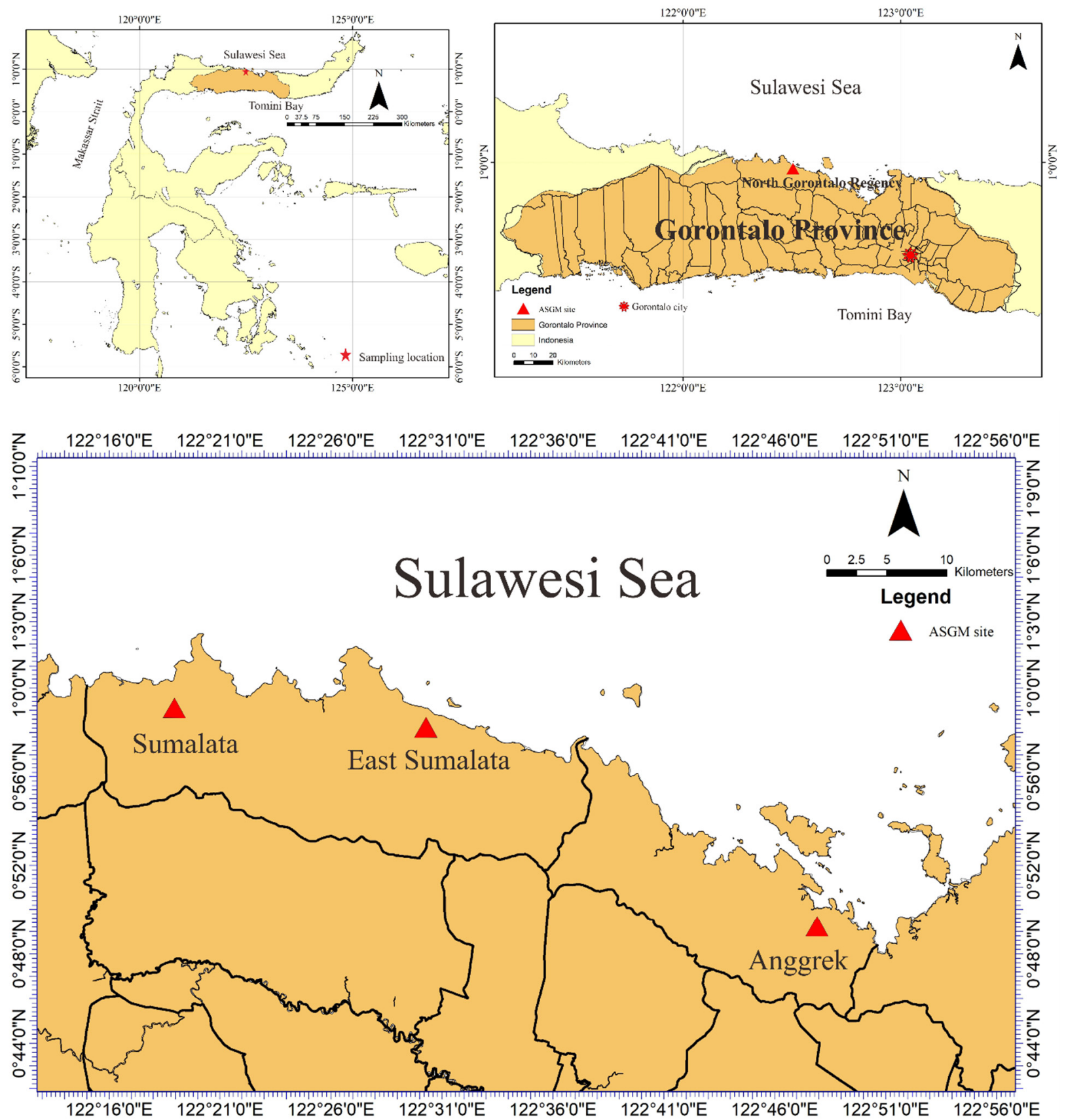

Figure 1. Artisanal and small-scale gold mining (ASGM) sites in North Gorontalo Regency, Gorontalo Province, Indonesia.

\subsection{Calculation of $\mathrm{THg}$}

The bioaccumulation of $\mathrm{Hg}$ was estimated using the $\mathrm{THg}$, defined as the dry weight of the sample multiplied by the $\mathrm{Hg}$ concentration determined by the PIXE analysis in $100 \mathrm{~cm}^{2}$ of sample [17].

$$
\mathrm{THg}=\left(\mathrm{DW} \times \mathrm{C}_{\mathrm{Hg}}\right) \times(\mathrm{FD} / \text { real square })
$$


where DW is the dry weight of the sample, $\mathrm{C}_{\mathrm{Hg}}$ is the $\mathrm{Hg}$ concentration, $\mathrm{FD}$ is fragment dimensions $\left(100 \mathrm{~cm}^{2}\right)$, and real square is the sample dimension, as measured by ImageJ.

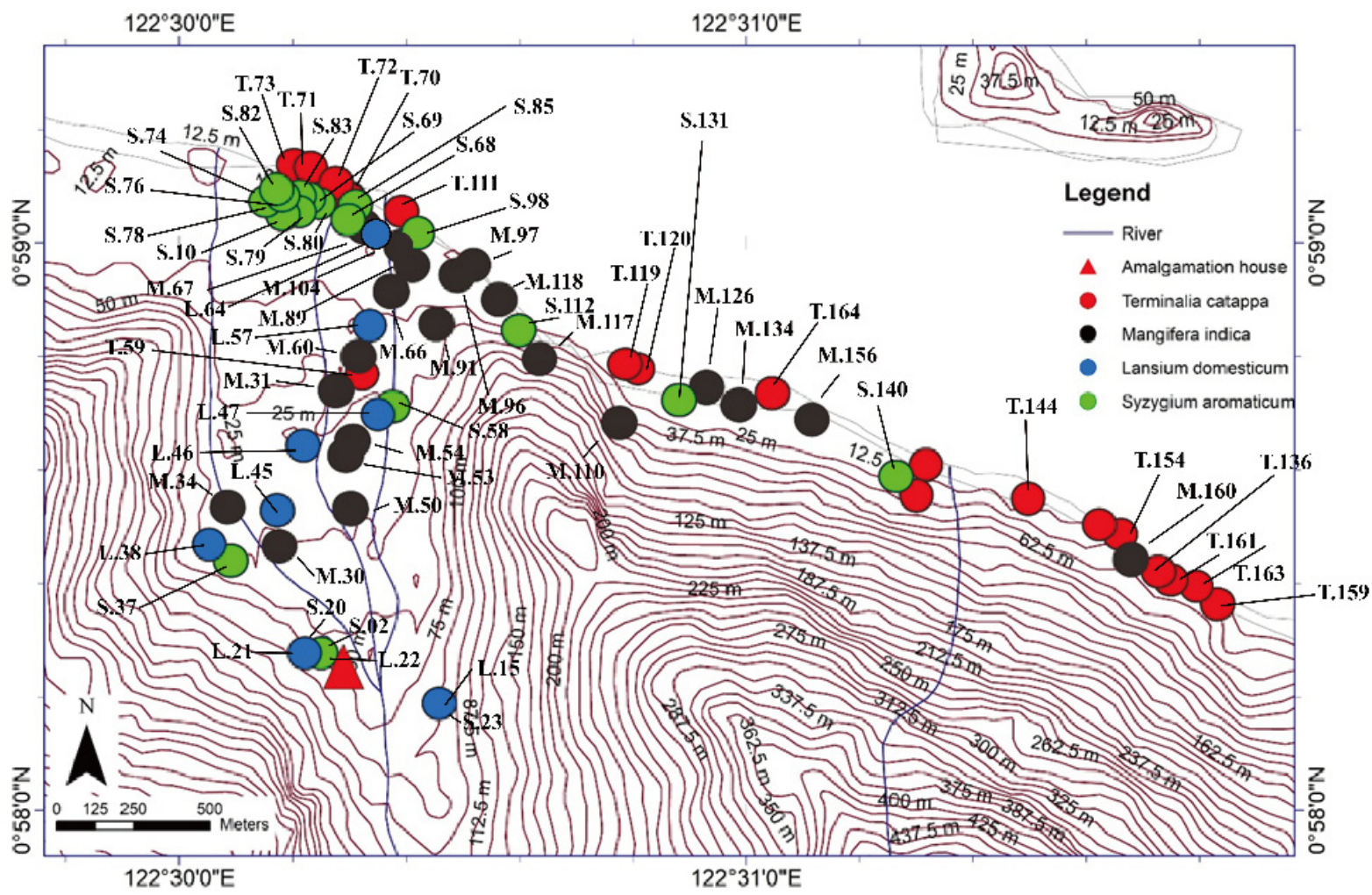

Figure 2. Terminalia catappa, Mangifera indica, Lansium domesticum, and Syzygium aromaticum sampling points in East Sumalata District, Gorontalo Province, Indonesia $(\mathrm{N}=65)$. The sampling point coordinates was measured using a GPS (Oregon 650 TCJ; Garmin), and the map contours were created by ArcGIS 10.3 and Global Mapper 10 software.

\subsection{Statistical Analysis}

Statistical analyses were performed using IBM SPSS Statistic 21 for Microsoft Windows. The Shapiro-Wilk test was used to check the normality of the $\mathrm{Hg}$ concentrations. The data were log-normally distributed, so the Kruskal-Wallis ANOVA test was used to test for significant differences, with $p<0.05$ considered statistically significant.

\section{Results}

\subsection{Estimation of $\mathrm{THg}$}

The THg in the M. indica bark samples ranged from not detected (ND) to $74.6 \mu \mathrm{g} \mathrm{DW}$ (see Table 1). The ND results were probably attributable to the absorption of $\mathrm{Hg}$ due to different weather conditions under different topographic conditions. The THg in the bark samples of S. aromaticum, T. catappa, and L. domesticum ranged from ND to 156.8, ND to 180, and ND to $63.4 \mu \mathrm{g}$ DW, respectively (see Tables 2 to 4 ). The average results of THg showed that the T. catappa has highest mean of THg about $66.2 \mu \mathrm{g}$ DW. Then, it was followed by S. aromaticum, M. indica, and L. domesticum with $\mathrm{THg}$ concentrations about 42.4, 26.1, and $15.4 \mu \mathrm{g}$ DW, respectively. The highest THg was located in areas of lower topography, as shown in Figure 3. This suggested that atmospheric $\mathrm{Hg}$ contamination is most dominant in estuaries. A plant is categorized as toxic if the concentration of $\mathrm{Hg}$ exceeds $1 \mathrm{ppm}$ [9], so based on this study results, the bark of M. indica, S. aromaticum, T. catappa and L. domesticum could be used as a biomonitoring of atmospheric $\mathrm{Hg}$ contamination in the environmental assessments of ASGM areas. 
Table 1. Total weight of $\mathrm{Hg}(\mathrm{THg})$ in the bark and diameter of Mangifera indica.

\begin{tabular}{cccc}
\hline No & Sample & T(Hg) $(\mu \mathbf{g}-\mathbf{D W}) \pm \mathbf{S D}$ & Diameter $(\mathbf{c m})$ \\
\hline 1 & M. indica 30 & $49.8 \pm 27.7$ & 42.7 \\
2 & M. indica 117 & $15.9 \pm 15.3$ & 40.1 \\
3 & M. indica 118 & $64.5 \pm 20.1$ & 46.8 \\
4 & M. indica 156 & $13.0 \pm 14.3$ & 25.5 \\
5 & M. indica 126 & $63.5 \pm 49.1$ & 30.3 \\
6 & M. indica 160 & ND & 19.1 \\
7 & M. indica 134 & $22.2 \pm 31.4$ & 27.4 \\
8 & M. indica 53 & $8.70 \pm 16.4$ & 20.7 \\
9 & M. indica 66 & $47.9 \pm 31.1$ & 69.7 \\
10 & M. indica 96 & ND & 23.9 \\
11 & M. indica 31 & $35.5 \pm 34.6$ & 72.6 \\
12 & M. indica 89 & ND & 36.3 \\
13 & M. indica 97 & $24.3 \pm 12.3$ & 89.2 \\
14 & M. indica 104 & $54.1 \pm 27.3$ & 47.8 \\
15 & M. indica 34 & $4.10 \pm 7.10$ & 41.4 \\
16 & M. indica 67 & $6.60 \pm 13.7$ & 11.8 \\
17 & M. indica 54 & ND & 29.9 \\
18 & M. indica 91 & $30.9 \pm 15.0$ & 24.2 \\
19 & M. indica 110 & $74.6 \pm 27.6$ & 43.9 \\
20 & M. indica 60 & $32.9 \pm 23.4$ & 58.3 \\
21 & M. indica 50 & ND & 41.1 \\
\hline
\end{tabular}

T: Total; DW: Dry Weight; SD: Standard Deviation; ND: Not Detected.

Table 2. Total weight of $\mathrm{Hg}(\mathrm{THg})$ in the bark and diameter of Syzygium aromaticum.

\begin{tabular}{cccc}
\hline No & Sample & $\mathbf{T}(\mathbf{H g})(\boldsymbol{\mu g}-\mathbf{D W}) \pm \mathbf{S D}$ & Diameter $\mathbf{( c m )}$ \\
\hline 1 & S. aromaticum 23 & $20.9 \pm 28.9$ & 11.1 \\
2 & S. aromaticum 79 & $9.10 \pm 18.2$ & 39.8 \\
3 & S. aromaticum 140 & $51.0 \pm 33.7$ & 19.1 \\
4 & S. aromaticum 68 & $24.2 \pm 28.5$ & 16.2 \\
5 & S. aromaticum 76 & $16.0 \pm 20.6$ & 33.4 \\
6 & S. aromaticum 69 & $31.2 \pm 48.5$ & 10.8 \\
7 & S. aromaticum 82 & $138 \pm 68.7$ & 18.5 \\
8 & S. aromaticum 112 & $156.8 \pm 79.6$ & 18.5 \\
9 & S. aromaticum 85 & $23.0 \pm 17.7$ & 13.7 \\
10 & S. aromaticum 20 & $58.8 \pm 33.3$ & 23.9 \\
11 & S. aromaticum 98 & $54.3 \pm 26.5$ & 25.5 \\
12 & S. aromaticum 10 & $\mathrm{ND}$ & 28.4 \\
13 & S. aromaticum 02 & $22.6 \pm 10.2$ & 29.8 \\
14 & S. aromaticum 83 & $39.5 \pm 27.4$ & 26.1 \\
15 & S. aromaticum 58 & $47.8 \pm 19.6$ & 10.5 \\
16 & S. aromaticum 78 & $\mathrm{ND}$ & 16.9 \\
17 & S. aromaticum 74 & $42.6 \pm 16.3$ & 17.2 \\
18 & S. aromaticum 37 & $41.3 \pm 23.5$ & 11.1 \\
19 & S. aromaticum 80 & $40.6 \pm 24.4$ & 30.6 \\
20 & S. aromaticum 131 & $29.6 \pm 15.3$ & 11.5 \\
\hline
\end{tabular}

T: Total; DW: Dry Weight; SD: Standard Deviation; ND: Not Detected. 
Table 3. Total weight of $\mathrm{Hg}(\mathrm{THg})$ in the bark and diameter of Terminalia catappa.

\begin{tabular}{cccc}
\hline No & Sample & T(Hg) $(\boldsymbol{\mu g}-\mathbf{D W}) \pm \mathbf{S D}$ & Diameter $(\mathbf{c m})$ \\
\hline 1 & T. catappa 71 & $8.70 \pm 22.0$ & 17.5 \\
2 & T. catappa 120 & $35.9 \pm 17.9$ & 20.7 \\
3 & T. catappa 136 & $68.4 \pm 26.3$ & 55.1 \\
4 & T. catappa 144 & ND & 17.8 \\
5 & T. catappa 163 & $150 \pm 42.4$ & 43.6 \\
6 & T. catappa 73 & $35.4 \pm 38.7$ & 32.8 \\
7 & T. catappa 164 & $113 \pm 69.7$ & 50.3 \\
8 & T. catappa 59 & $180 \pm 105$ & 44.9 \\
9 & T. catappa 72 & $26.4 \pm 43.5$ & 41.7 \\
10 & T. catappa 70 & $92.7 \pm 43.6$ & 36.6 \\
11 & T. catappa 159 & $72.5 \pm 56.4$ & 58.9 \\
12 & T. catappa 119 & $40.1 \pm 69.4$ & 53.8 \\
13 & T. catappa 154 & $\mathrm{ND}$ & 89.5 \\
14 & T. catappa 161 & $16.8 \pm 19.2$ & 53.8 \\
15 & T. catappa 111 & $152 \pm 63.3$ & 31.5 \\
\hline
\end{tabular}

T: Total; DW: Dry Weight; SD: Standard Deviation; ND: Not Detected.

Table 4. Total weight of $\mathrm{Hg}(\mathrm{THg})$ in the bark and diameter of Lansium domesticum.

\begin{tabular}{cccc}
\hline No & Sample & $\mathbf{T}(\mathbf{H g})(\boldsymbol{\mu g}-\mathbf{D W}) \pm \mathbf{S D}$ & Diameter $(\mathbf{c m})$ \\
\hline 1 & L. domesticum 26 & $25.0 \pm 18.8$ & 38.5 \\
2 & L. domesticum 57 & ND & 34.1 \\
3 & L. domesticum 64 & $10.7 \pm 14.7$ & 37.6 \\
4 & L. domesticum 38 & $2.50 \pm 15.5$ & 37.9 \\
5 & L. domesticum 45 & $14.1 \pm 25.1$ & 38.5 \\
6 & L. domesticum 15 & ND & 30.7 \\
7 & L. domesticum 47 & $63.4 \pm 26.8$ & 27.4 \\
8 & L. domesticum 21 & $13.0 \pm 13.6$ & 10.4 \\
9 & L. domesticum 46 & $9.50 \pm 25.0$ & 10.5 \\
\hline
\end{tabular}

T: Total; DW: Dry Weight; SD: Standard Deviation; ND: Not Detected.

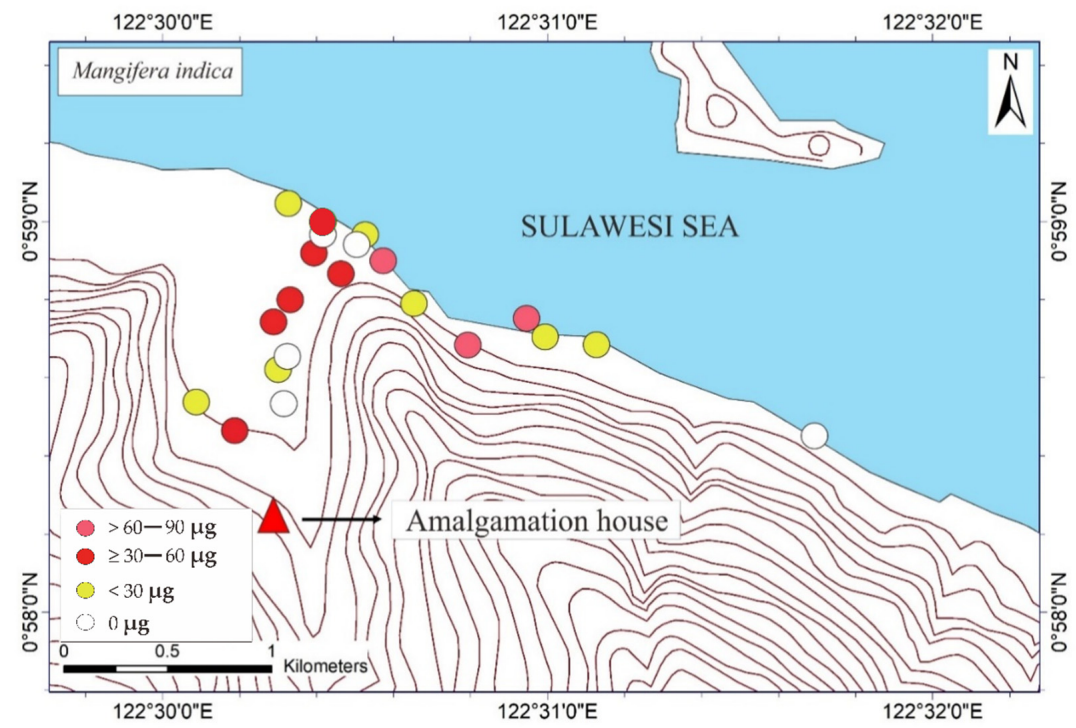

Figure 3. Cont. 

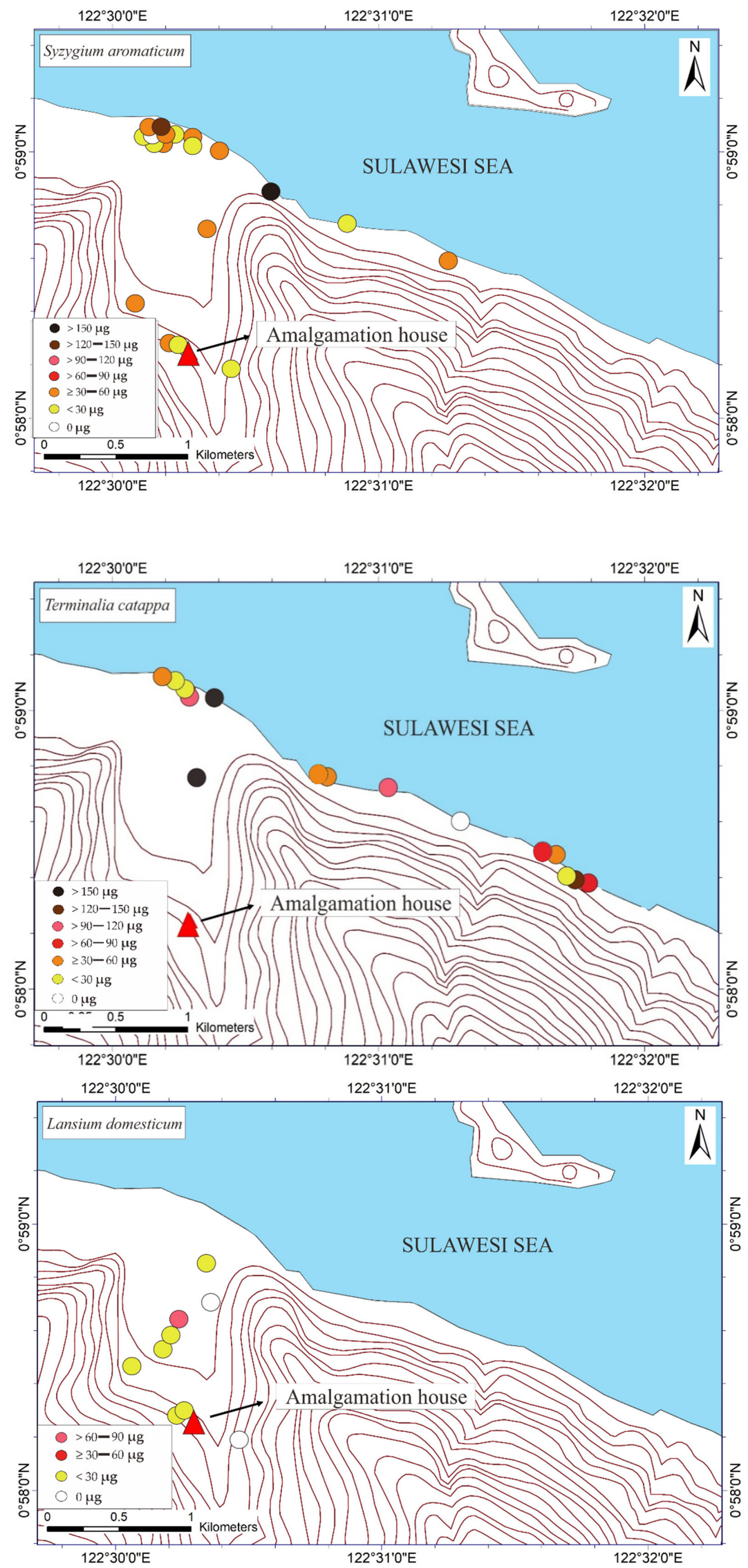

Figure 3. Mapped distribution of total weight of $\mathrm{Hg}(\mathrm{THg})$ in the bark of Mangifera indica, Syzygium aromaticum, Terminalia catappa, and Lansium domesticum $(N=65)$. 


\section{Discussion}

\subsection{Mapping Distribution of THg in ASGM Area}

The mapped distribution of THg in the bark of $M$. indica, S. aromaticum, T. catappa and $L$. domesticum (Figure 3) suggested that topography significantly influences the accumulation of $\mathrm{Hg}$ in the atmosphere together with local weather conditions. However, the distribution was not affected by the distance to the amalgamation site, as shown in Figures 3 and 4. This is probably attributable to the wind direction, which transports and deposits the atmospheric $\mathrm{Hg}$ in the estuary area. The concentrations on the tree barks were affected by atmospheric attachment to the barks, not from the root absorption in soil and/or water [17].

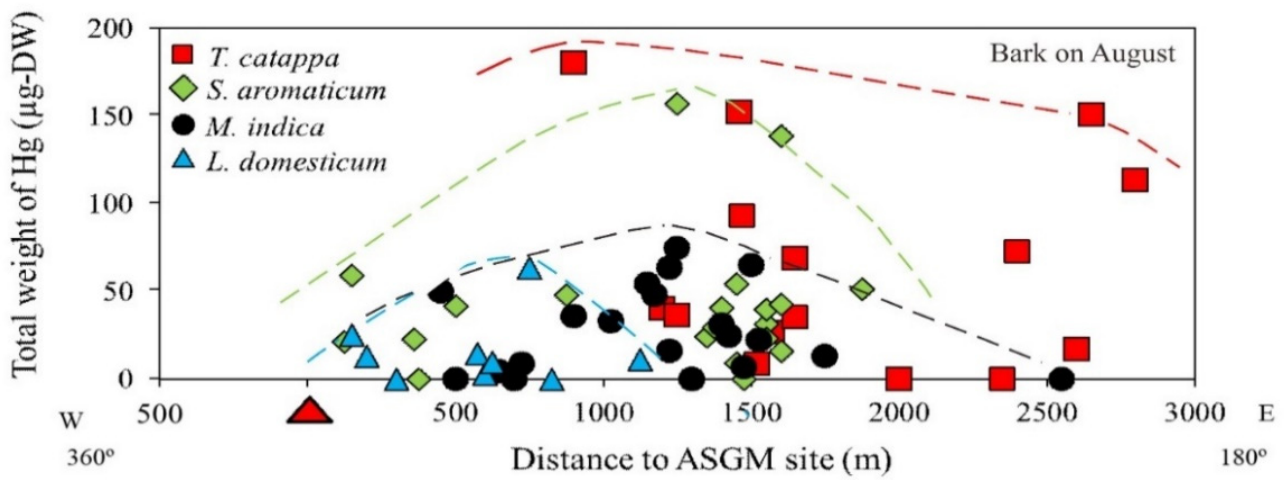

Figure 4. Total weight of $\mathrm{Hg}(\mathrm{THg})$ in the bark of various tree species.

Zang et al.'s [18] study showed that Hg transport and dispersion in the atmosphere may not always be explained by so-called prevailing winds. In their study area, there was no prevailing wind strong enough to control the direction of the $\mathrm{Hg}$ diffusion in the atmosphere, so the evenly distributed $\mathrm{Hg}$ in their bark samples was attributed to precipitation rather than dry deposition or contamination from a reservoir. Local influences can diminish the relative importance of the general atmospheric transport of $\mathrm{Hg}$ [18]. According to Barnes et al. [19], tree bark accumulates metals as a function of its proximity to the pollution source.

Elemental $\mathrm{Hg}$ is the predominant (95\%) form in the atmosphere, with reactive and particulate forms also being important [20]. Plants have been shown to accumulate atmospheric elemental $\mathrm{Hg}\left(\mathrm{Hg}^{\mathrm{O}}\right)$ in foliage over time as a function of exposure to concentrations of $\mathrm{Hg}$ in the air and soil [21,22]. Elemental $\mathrm{Hg}$ is thought to be directly taken up via stomata and/or cuticles and possibly transformed into a water-soluble $\mathrm{Hg}$ compound and absorbed via leaves $[23,24]$. In addition to the concentration of atmospheric $\mathrm{Hg}$, environmental factors, such as solar irradiation, air temperature, altitude, and biological factors, such as plant species, leaf age, and leaf placement, also significantly influence the uptake of $\mathrm{Hg}$ by foliage [22,25-27].

In addition, climate change has the potential to alter the sequestration of $\mathrm{Hg}$ from forest soils via direct pressures (meteorological) or indirect pressures (vegetation changes) [28]. This could have indirect consequences for forests that may also affect $\mathrm{Hg}$ cycling. According to Richardson and Friedland [28], vegetation type can affect many aspects of $\mathrm{Hg}$ cycling in forest soils. The variable foliar morphology and biomass characteristics of different vegetation types can affect $\mathrm{Hg}$ levels in litterfall. The physical attributes of the canopy structure of each species can also directly affect the accumulation of $\mathrm{Hg}$ in foliage [29,30].

\subsection{Distribution of THg Based on Distance to Source and Elevation}

The distance of the samples from the ASGM site did not influence the THg attachment; however, the total weight of $\mathrm{Hg}$ in the bark taken from T. catappa was higher compared to $S$. aromaticum, M. indica, and L. domesticum, as shown in Figure 4. In the study area, T. catappa and $M$. indica grow naturally, whereas S. aromaticum and L. domesticum are cultivated for economic purposes. 
Living at lower topographic levels along the coastline, T. catappa is mainly an estuary plant, and some of the $S$. aromaticum sampled in this study was also cultivated at lower topographic levels along the coastline. As shown in Section 3.1, the highest THg was found in the S. aromaticum and T. catappa, located in the coastline area.

A wide range of total $\mathrm{Hg}$ concentrations in the air has been reported in the literature. The latitudinal distribution of total gaseous $\mathrm{Hg}$ indicates a background level of about $2 \mathrm{ng} \mathrm{m}^{-3}$ in the lower troposphere of the northern hemisphere and just over $1 \mathrm{ng} \mathrm{m}^{-3}$ in the southern hemisphere, at least in an oceanic environment [31]. In general, elemental $\mathrm{Hg}$ seems to be the dominant form [31]. The Hg associated with aerosol particles normally makes up only a small fraction of the total airborne $\mathrm{Hg}$; however, the role of particulate $\mathrm{Hg}$ in the atmospheric is important. The atmospheric cycle retains $\mathrm{Hg}$ in the atmosphere for long periods, and, consequently, transports it over very long distances [32]. Mercury vapor, which comprises $95-99 \%$ of total $\mathrm{Hg}$ in the atmosphere, has an atmospheric residence time of 1 year [4], allowing for global dispersal and the contamination of ecosystems through both wet and dry deposition [33,34].

\subsection{Distribution of $\mathrm{THg}$ Based on Tree Species}

A THg boxplot for the various tree species showed that the mean values for T. catappa, S. aromaticum, $M$. indica, and L. domesticum were 66.2, 42.4, 26.1, and $15.4 \mu \mathrm{g}$-DW, respectively, but there were no significant differences $(p<0.05)$, as shown in Figure 5. This indicated that tree species significantly influenced the attachment of Hg to the bark. We assumed that T. catappa bark has a high porosity, so it retains $\mathrm{Hg}$ better than the other species.

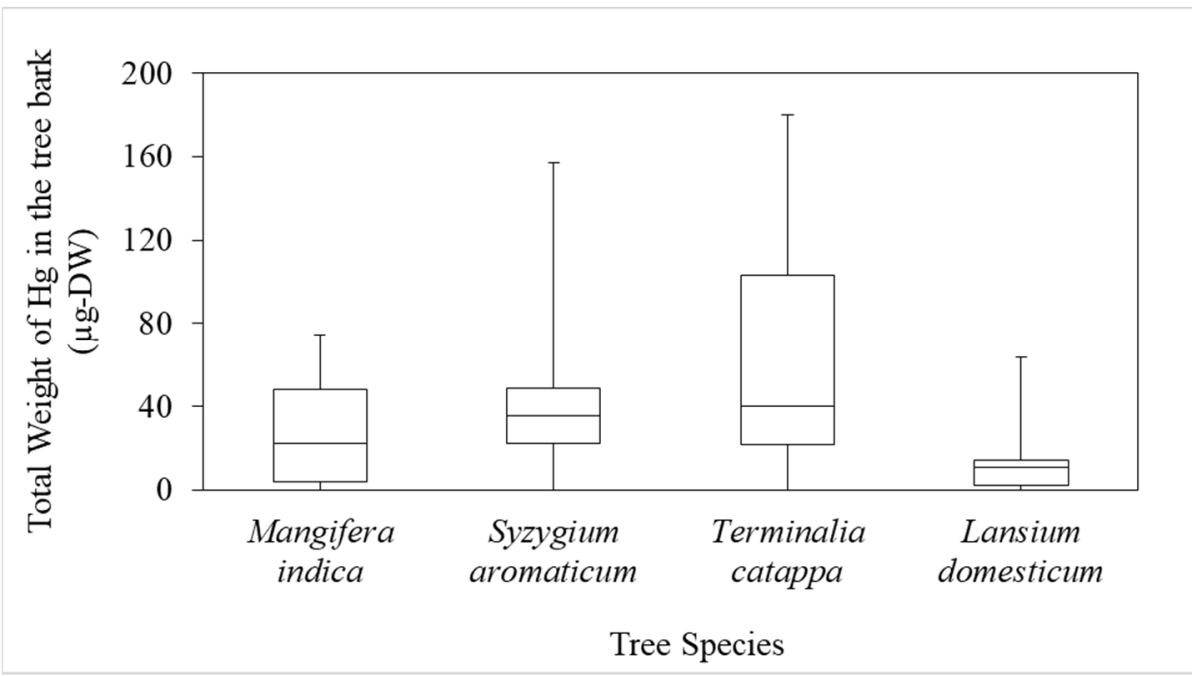

Figure 5. Boxplot of the total weight of $\mathrm{Hg}(\mathrm{THg})$ in the bark of the various species.

\section{Conclusions}

Our results showed that there was a high level of heterogeneity in the THg in the bark of both the naturally grown and cultivated tropical tree species we studied. The sampled M. indica and T. catappa were located in areas of lower topography on the coastline of the study area. M. indica is a native plant mostly cultivated close to houses as a garden plant. S. aromaticum and L. domesticum are native plants cultivated for economic purposes in the study area. This variability suggested that topography significantly influenced the accumulation of $\mathrm{Hg}$ together with local weather conditions, but was not affected by distance from the amalgamation site. This study indicated that tree species significantly influenced the attachment of $\mathrm{Hg}$ to the bark. We assumed that T. catappa bark has a high porosity, so it retains $\mathrm{Hg}$ better than the other species. We found that the tree bark of $M$. indica, S. aromaticum, T. catappa and L. domesticum could be used as a biomonitoring of atmospheric contamination assessment in the ASGM area. 


\begin{abstract}
Author Contributions: All authors contributed to the work presented in this manuscript. H.P., as principal researcher, undertook this work in association with his $\mathrm{PhD}$ program at Ehime University. M.S. is his PhD supervisor. J.S.L. provided the micro-PIXE measurement of the tree bark samples, and K.S. provided the PIXE measurement of the tree bark samples. All authors have read and agreed to the published version of the manuscript.
\end{abstract}

Funding: This research was funded by Research Institute for Humanity and Nature Project No. 14200102. This work was also supported by JSPS KAKENHI Grant Number 16H02706.

Institutional Review Board Statement: Not applicable.

Informed Consent Statement: Not applicable.

Acknowledgments: Hendra Prasetia wishes to thank the Japanese Government for providing a Monbukagakusho Scholarship for graduate studies at Ehime University, RIHN for funding this research and the North Gorontalo Regency Government of Gorontalo Province that allowed the authors to conduct the research activity.

Conflicts of Interest: The authors declare no conflict of interest.

\title{
References
}

1. Hinton, J.J.; Veiga, M.M.; Veiga, A.T.C. Clean Artisanal Gold Mining: A Utopian Approach? J. Clean. Prod. 2003, 11, 99-115. [CrossRef]

2. Veiga, M.M.; Maxson, P.A.; Hylander, L.D. Origin and Consumption of Mercury in Small-Scale Gold Mining. J. Clean. Prod. 2006, 14, 436-447. [CrossRef]

3. Taylor, H.; Appleton, J.D.; Lister, R.; Smith, B.; Chitamweba, D.; Mkumbo, O.; Machiwa, J.F.; Tesha, A.L.; Beinhoff, C. Environmental Assessment of Mercury Contamination from the Rwamagasa Artisanal Gold Mining Centre, Geita District, Tanzania. Sci. Total Environ. 2005, 343, 111-133. [CrossRef] [PubMed]

4. $\quad$ Fitzgerald, W.F.; Engstrom, D.R.; Mason, R.P.; Nater, E.A. The Case for Atmospheric Mercury Contamination in Remote Areas. Environ. Sci. Technol. 1998, 32, 1-7. [CrossRef]

5. Rasmussen, P.E. Temporal Variation of Mercury in Vegetation. In Mercury as a Global Pollutant; Springer: Berlin/Heidelberg, Germany, 1995; Volume 80, pp. 1039-1042. [CrossRef]

6. Tomiyasu, T.; Kono, Y.; Kodamatani, H.; Hidayati, N.; Rahajoe, J.S. The Distribution of Mercury Around the Small-Scale Gold Mining Area Along the Cikaniki River, Bogor, Indonesia. Environ. Res. 2013, 125, 12-19. [CrossRef] [PubMed]

7. Vtorova, V.N. Substantiation of Methods and Objects of Observations over Chemical Composition of Plants During Monitoring of Forest Ecosystem. Inf. Bull. Probl. III Counc. Mutual Econ. Help 1987, 1, 1-2.

8. Vtorova, V.N. Quantitative Evaluation of the Chemical Similarity of Needles of Picea Schrenkiana with Other Spruce Species in Natural and Artificial Growth Conditions. Biol. Bull. Acad. Sci. USSR 1991, 17, 245-253.

9. Kabata-Pendias, A.; Pendias, H. Trace Elements in Soils and Plants; CRC Press: Boca Raton, FL, USA, 1984 ; Volume 315.

10. Geagea, M.L.; Stille, P.; Millet, M.; Perrone, T. REE Characteristics and Pb, Sr and Nd Isotopic Compositions of Steel Plant Emissions. Sci. Total Environ. 2007, 373, 404-419. [CrossRef]

11. Catinon, M.; Ayrault, S.; Boudouma, O.; Asta, J.; Tissut, M.; Ravanel, P. The Inclusion of Atmospheric Particles into the Bark Suber of Ash Trees. Chemosphere 2009, 77, 1313-1320. [CrossRef] [PubMed]

12. Olajire, A.A.; Ayodele, E.T. Study of Atmospheric Pollution Levels by Trace Elements Analysis of Tree Bark and Leaves. Bull. Chem. Soc. Ethiop. 2003, 17, 11-17. [CrossRef]

13. Markert, B. Presence and Significance of Naturally Occurring Chemical Elements of the Periodic System in the Plant Organism and Consequences for Future Investigations on Inorganic Environmental Chemistry in Ecosystems. Plant Ecol. 1992, $103,1-30$.

14. Fostier, A.H.; Santos, C.; Carpi, A.; Windm, C.C.; Melendez-Perez, J.J. Soil and biomass mercury emissions during a prescribed fi re in the Amazonian rain forest. Environ. Res. 2014, 96, 415-422.

15. Sera, K.; Yanagisawa, T.; Tsunoda, H.; Futatsugawa, S.; Hatakeyama, S.; Saitoh, Y.; Suzuki, S.; Orihara, H. Bio-PIXE at the Takizawa Facility (Bio-PIXE with a Baby Cyclotron). Int. J. PIXE 1992, 02, 325-330. [CrossRef]

16. Prasetia, H.; Sakakibara, M.; Sueoka, Y.; Sera, K. Pteris cretica as a Potential Biomarker and Hyperaccumulator in an Abandoned Mine Site, Southwest Japan. Environments 2016, 3, 15. [CrossRef]

17. Prasetia, H.; Sakakibara, M.; Omori, K.; Laird, J.S.; Sera, K.; Kurniawan, I.A. Mangifera indica as Bioindicator of Mercury Atmospheric Contamination in an ASGM Area in North Gorontalo Regency, Indonesia. Geosciences 2018, 8, 31. [CrossRef]

18. Zhang, L.; Qian, J.-L.; Planas, D. Mercury Concentration in Tree Rings of Black Spruce (Picea mariana Mill. BSP) in Boreal Quebec, Canada. Water Air Soil Pollut. 1995, 81, 163-173. [CrossRef]

19. Barnes, D.; Hamadah, M.A.; Ottaway, J.M. The Lead, Copper and Zinc Content of Tree Rings and Bark A Measurement of Local Metallic Pollution. Sci. Total Environ. 1976, 5, 63-77. [CrossRef]

20. Millhollen, A.G.; Gustin, M.S.; Obrist, D. Foliar Mercury Accumulation and Exchange for Three Tree Species. Environ. Sci. Technol. 2006, 40, 6001-6006. [CrossRef] [PubMed] 
21. Frescholtz, T.E.; Gustin, M.S.; Schorran, D.E.; Fernandez, G.C.J. Assessing the Source of Mercury in Foliar Tissue of Quaking Aspen. Environ. Toxicol. Chem. 2003, 22, 2114-2119. [CrossRef] [PubMed]

22. Ericksen, J.A.; Gustin, M.S.; Schorran, D.E.; Johnson, D.W.; Lindberg, S.E.; Coleman, J.S. Accumulation of Atmospheric Mercury in Forest Foliage. Atmos. Environ. 2003, 37, 1613-1622. [CrossRef]

23. Browne, C.L.; Fang, S.C. Uptake of Mercury Vapor by Wheat: An Assimilation Model. Plant Physiol. 1978, 61, 430-433. [CrossRef]

24. Lindberg, S.E.; Stratton, W.J. Atmospheric Mercury Speciation: Concentrations and Behavior of Reactive Gaseous Mercury in Ambient Air. Environ. Sci. Technol. 1998, 32, 49-57. [CrossRef]

25. Zhu, W.; Lin, C.-J.; Wang, X.; Sommar, J.; Fu, X.; Feng, X. Global Observations and Modeling of Atmosphere-Surface Exchange of Elemental Mercury: A Critical Review. Atmos. Chem. Phys. 2016, 16, 4451-4480. [CrossRef]

26. Kos, G.; Ryzhkov, A.; Dastoor, A.; Narayan, J.; Steffen, A.; Ariya, P.A.; Zhang, L. Evaluation of Discrepancy Between Measured and Modelled Oxidized Mercury Species. Atmos. Chem. Phys. 2013, 13, 4839-4863. [CrossRef]

27. Laacouri, A.; Nater, E.A.; Kolka, R.K. Distribution and Uptake Dynamics of Mercury in Leaves of Common Deciduous Tree Species in Minnesota, USA. Environ. Sci. Technol. 2013, 47, 10462-10470. [CrossRef]

28. Richardson, J.B.; Friedland, A.J. Mercury in Coniferous and Deciduous Upland Forests in Northern New England, USA: Implications of Climate Change. Biogeosciences 2015, 12, 6737-6749. [CrossRef]

29. Obrist, D.; Johnson, D.W.; Lindberg, S.E.; Luo, Y.; Hararuk, O.; Bracho, R.; Battles, J.J.; Dail, D.B.; Edmonds, R.L.; Monson, R.K.; et al. Mercury Distribution Across 14 US Forests. Part I: Spatial Patterns of Concentrations in Biomass, Litter, and Soils. Environ. Sci. Technol. 2011, 45, 3974-3981. [CrossRef] [PubMed]

30. Blackwell, B.D.; Driscoll, C.T. Deposition of Mercury in Forests Along a Montane Elevation Gradient. Environ. Sci. Technol. 2015, 49, 5363-5370. [CrossRef]

31. Lindqvist, O.; Rodhe, H. Atmospheric Mercury, a Review. Tellus B 1985, 37, 136-156. [CrossRef]

32. Friedli, H.R.; Radke, L.F.; Payne, N.J.; McRae, D.J.; Lynham, T.J.; Blake, T.W. Mercury in Vegetation and Organic Soil at an Upland Boreal Forest Site in Prince Albert National Park, Saskatchewan, Canada. J. Geophys. Res. 2007, 112. [CrossRef]

33. Vandal, G.M.; Mason, R.P.; Fitzgerald, W.F. Cycling of Volatile Mercury in Temperate Lakes. Water Air Soil Pollut. 1991, 56, 791-803. [CrossRef]

34. Zillioux, E.J.; Porcella, D.B.; Benoit, J.M. Mercury Cycling and Effects in Freshwater Wetland Ecosystems. Environ. Toxicol. Chem. 1993, 12, 2245-2264. [CrossRef] 